\title{
Comparison of cell types in the rat Leydig cell lineage after ethane dimethanesulfonate treatment
}

\author{
Jingjing Guo ${ }^{1}$, Hongyu Zhou ${ }^{2}$, Zhijian $\mathrm{Su}^{3}$, Bingbing Chen ${ }^{2}$, Guimin Wang ${ }^{1}$, Claire Q F Wang ${ }^{1}$, \\ Yunfei Xu ${ }^{4}$ and Ren-Shan Ge $e^{1,5}$ \\ ${ }^{1}$ Institute of Reproductive Biomedicine and the 2nd Affiliated Hospital, Wenzhou Medical College, Wenzhou, \\ Zhejiang 325027, People's Republic of China, ${ }^{2}$ School of Pharmacy, Wenzhou Medical College, Wenzhou, \\ Zhejiang 325000, People's Republic of China, ${ }^{3}$ Biopharmaceutical Research and Development Centre, Jinan \\ University, Guangzhou 510632, People's Republic of China, ${ }^{4}$ Department of Urology, the Affiliated 10th People's \\ Hospital of Tongji University, Shanghai, People's Republic of China and ${ }^{5}$ Population Council, Rockefeller University, \\ 1230 York Avenue, New York, New York 10065, USA
}

Correspondence should be addressed to R-S Ge; Email: r_ge@yahoo.com; Y Xu; Email: xuyunfeibb@sina.com

J Guo and $\mathrm{H}$ Zhou contributed equally to this work

\begin{abstract}
The objective of this study was to purify cells in the Leydig cell lineage following regeneration after ethane dimethanesulfonate (EDS) treatment and compare their steroidogenic capacity. Regenerated progenitor (RPLCs), immature (RILCs), and adult Leydig cells (RALCs) were isolated from testes 21, 28 and 56 days after EDS treatment respectively. Production rates for androgens including androsterone and $5 \alpha$-androstane-17 $\beta, 3 \alpha$-diol (DIOL), testosterone and androstenedione were measured in RPLCs, RILCs and RALCs in media after 3-h in vitro culture with $100 \mathrm{ng} / \mathrm{ml} \mathrm{LH}$. Steady-state mRNA levels of steroidogenic enzymes and their activities were measured in freshly isolated cells. Compared to adult Leydig cells (ALCs) isolated from normal 90-day-old rat testes, which primarily produce testosterone $\mathbf{( 6 9 . 7 3 \% ) , ~ R P L C s ~ a n d ~ R I L C s ~ p r i m a r i l y ~ p r o d u c e d ~ a n d r o s t e r o n e ~} \mathbf{( 7 0 . 2 1 \% )}$ and DIOL $(69.79 \%)$ respectively. Leydig cells isolated from testes 56 days post-EDS showed equivalent capacity of steroidogenesis to ALCs and primarily produced testosterone (72.90\%). RPLCs

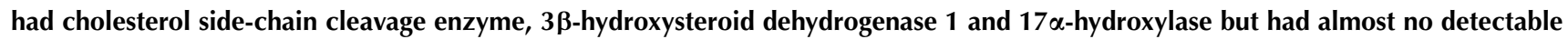
$17 \beta$-hydroxysteroid dehydrogenase 3 and 11 $\beta$-hydroxysteroid dehydrogenase 1 activities, while RILCs had increased $17 \beta$-hydroxysteroid dehydrogenase 3 and 11 $\beta$-hydroxysteroid dehydrogenase 1 activities. Because RPLCs and RILCs had higher $5 \alpha$-reductase 1 and $3 \alpha$-hydroxysteroid dehydrogenase activities they produced mainly $5 \alpha$-reduced androgens. Real-time PCR confirmed the similar trends for the expressions of these steroidogenic enzymes. In conclusion, the purified RPLCs, RILCs and RALCs are similar to those of their counterparts during rat pubertal development.
\end{abstract}

Reproduction (2013) 145 371-380

\section{Introduction}

Testosterone is essential for the maintenance of sperm production and male secondary sexual characteristics in adult males. In mature males, testosterone is primarily produced by testicular Leydig cells. Mature Leydig cells, here referred to as adult Leydig cells (ALCs), have been found to come from stem Leydig cells that are present in the testicular interstitium (Ge et al. 2006). In the rat postnatal development of ALCs can be divided into four stages conceptually: stem, progenitor, immature and adult Leydig cells. Stem Leydig cells are present in the testicular interstitium through life and they are spindle shaped without Leydig cell biomarkers such as LH receptor $3 \beta$-hydroxysteroid dehydrogenase 1 ( $3 \beta \mathrm{HSD} 1$, encoded by $H s d 3 b 1)$, but contain stem cell biomarkers such as platelet-derived growth factor receptor $\alpha$, c-kit and nestin (Davidoff et al. 2004). We speculate that stem Leydig cells self-renew to keep the homeostasis of adult population of Leydig cells. At postnatal day 11-14 stem Leydig cells commit to spindle-shaped progenitor Leydig cells (Ariyaratne et al. 2000), which express some androgen biosynthetic enzymes including cytochrome P450 side-chain cleavage enzyme (CYP11A1, encoded by Cyp11a1), 3ßHSD1, and 17 $\alpha$-hydroxylase/20-lyase (CYP17A1, encoded by Cyp17a1) without expression of $17 \beta$-hydroxysteroid dehydrogenase 3 (17ßHSD3, encoded by Hsd17b3) (Ge \& Hardy 1998). Progenitor Leydig cells also contain high levels of $5 \alpha$-reductase 1 (SRD5A1, encoded by Srd5a1) and 3 $\alpha$-hydroxysteroid 
dehydrogenase ( $3 \alpha \mathrm{HSD}$, encoded by Akr1c14) (Ge \& Hardy 1998), thus the androgen precursor androstenedione formed by androgen biosynthetic enzymes is further metabolized into androsterone (Ge \& Hardy 1998). By postnatal day 28 progenitor Leydig cells develop into round lipid droplets containing immature Leydig cells (Ge \& Hardy 2007). Immature Leydig cells begin to express $17 \beta \mathrm{HSD} 3$ but still have higher levels of SRD5A 1 and $3 \alpha \mathrm{HSD}$. Therefore, they primarily produce $5 \alpha$-androstane-17 $\beta, 3 \alpha$,-diol (DIOL; Ariyaratne et al. 2000). SRD5A1 disappears in Leydig cells when immature Leydig cells differentiate into ALCs, leading to testosterone becoming the primary androgen (Ge \& Hardy 1998). Interestingly, a glucocorticoid-metabolizing enzyme, $11 \beta$-hydroxysteroid dehydrogenase 1 (11ßHSD1, encoded by Hsd11b1), starts its expression in immature Leydig cells of rat testis at postnatal day 28 (Phillips et al. 1989, Neumann etal. 1993, Ge etal. 1997). $11 \beta \mathrm{HSD} 1$ is a biomarker for Leydig cell development in adult population and plays a role in the regulation of testosterone production (Hu et al. 2008).

Postnatal Leydig cell development can be mimicked in a Leydig cell-depleted rat model by ethane dimethanesulfonate (EDS; Teerds 1996). One i.p. injection of $75 \mathrm{mg} / \mathrm{kg}$ EDS to a rat can specifically kill all mature Leydig cells in the testicular interstitium (Teerds 1996). Seven days post-EDS, all Leydig cells are killed, and the first morphologically recognizable and $3 \beta \mathrm{HSD} 1$-positive Leydig cells appear at day 14 post-EDS, and these cells are referred to as regenerated progenitor Leydig cells (RPLCs; Bartlett et al. 1986, Teerds et al. 1994, Teerds 1996). RPLCs differentiate into round lipid dropletscontaining cells at 28 days post-EDS. These cells are still immature, here referred to as regenerated immature Leydig cells (RILCs). SRD5A1 activity reaches its peak in the RILC stage and decreases dramatically thereafter (Vreeburg et al. 1988, O'Shaughnessy \& Murphy 1991). Around 56 days post-EDS Leydig cells are fully mature and produce testosterone, and these cells are referred to as regenerated adult Leydig cells (RALCs). There is little known for their identity of regenerated Leydig cells. In this study, we isolated these cell types from the Leydig cell lineage in the EDS-treated rat testes and compared their androgen types produced, steroidogenic capacity, and enzyme activities.

\section{Results \\ Leydig cell regeneration post-EDS}

As shown in Figs 1 and 2, 4 days post-EDS, only very few $3 \beta$ HSD1-positive cells were left ( $1-5 \%$ cells). Seven days post-EDS administration there were no $3 \beta \mathrm{HSD} 1$-positive cells in the testis, indicating that all Leydig cells were killed. $11 \beta$ HSD1 was also undetectable 7 and 14 days post-EDS, indicating that $11 \beta \mathrm{HSD} 1$ is only expressed in immature Leydig cells and ALCs. However, $3 \beta \mathrm{HSD} 1$ - and
$11 \beta \mathrm{HSD} 1$-positive cells were not proportionally regenerated. $3 \beta \mathrm{HSD} 1$-positive cells were 15.7 and $34.5 \%$ of the pre-treatment level at days 21 and 28 post-EDS respectively (Fig. 2A), while $11 \beta \mathrm{HSD} 1$-positive cells were only 4.5 and $35.1 \%$ of the pre-treatment level (Fig. 2B). These data indicate that 21 days post-EDS, cells in the Leydig cell lineage were mostly RPLCs as most $3 \beta \mathrm{HSD} 1$-positive cells regenerated at this time were not stained with $11 \beta \mathrm{HSD} 1$, a biomarker for immature Leydig cells during puberty (Phillips et al. 1989).

\section{Androgens produced by Leydig cells}

RPLCs, RILCs and RALCs were isolated from testes 21, 28 and 56 days post-EDS respectively and compared to ALCs isolated from 90-day-old normal rat testes. The isolation of each cell type was repeated four times. RPLCs were identified by the positive $3 \beta \mathrm{HSD} 1$ and SRD5A1 staining but not the negative $11 \beta \mathrm{HSD} 1$ staining (Supplementary Figure 1, see section on supplementary data given at the end of this article). RILCs were identified by the positive $3 \beta \mathrm{HSD} 1$ and $11 \beta \mathrm{HSD} 1$ staining but not the negative CYP2A1 staining (Supplementary Figure 1). RALCs and ALCs were identified by the positive CYP2A1 staining but not the negative staining of SRD5A1 (Supplementary Figure 1). All the cell types were confirmed, being progenitor, immature and adult after regeneration. The total androgen profiles showed that, after the stimulation of LH, ALCs, RPLCs, RILCs and RALCs produced $470.1 \pm 38.5,124.1 \pm 9.9,243.5 \pm 4.64$ and 485.7 $\pm 32.7 \mathrm{ng}$ androgen $/ 10^{6}$ cells respectively (Fig. 3 ). The androgen-producing capacity of RALCs was comparable to that of ALCs but twofold higher than that of RILCS and fourfold higher than that of RPLCs. LH-stimulated androgen end products produced by regenerated Leydig cells were different. Androsterone was the primary androgen secreted by RPLCs because this steroid constituted $70.21 \%$ of the total androgens. Parallel measurements showed that DIOL was the primary androgen for RILCs ( $69.79 \%$ of total androgens), and testosterone was the primary androgen for RALCs $(72.90 \%$, Fig. 3), which was comparable to that of ALCs (69.73\%).

The synthesis of testosterone and DIOL requires $17 \beta \mathrm{HSD} 3$ enzyme, and the low release rates for these steroids from RPLCs suggest that the amount of $17 \beta \mathrm{HSD} 3$ is low in this cell type. Androsterone and DIOL require the activities of SRD5A1 and 3 $\alpha \mathrm{HSD}$, and the high release rates of these steroids by RPLCs and RILCs indicate that androgen-metabolizing enzymes are most highly expressed in Leydig cells before the completion of regeneration.

\section{Steroidogenic enzyme activities}

The underlying basis for the different profiles of androgen release from these distinct stages of Leydig cell 

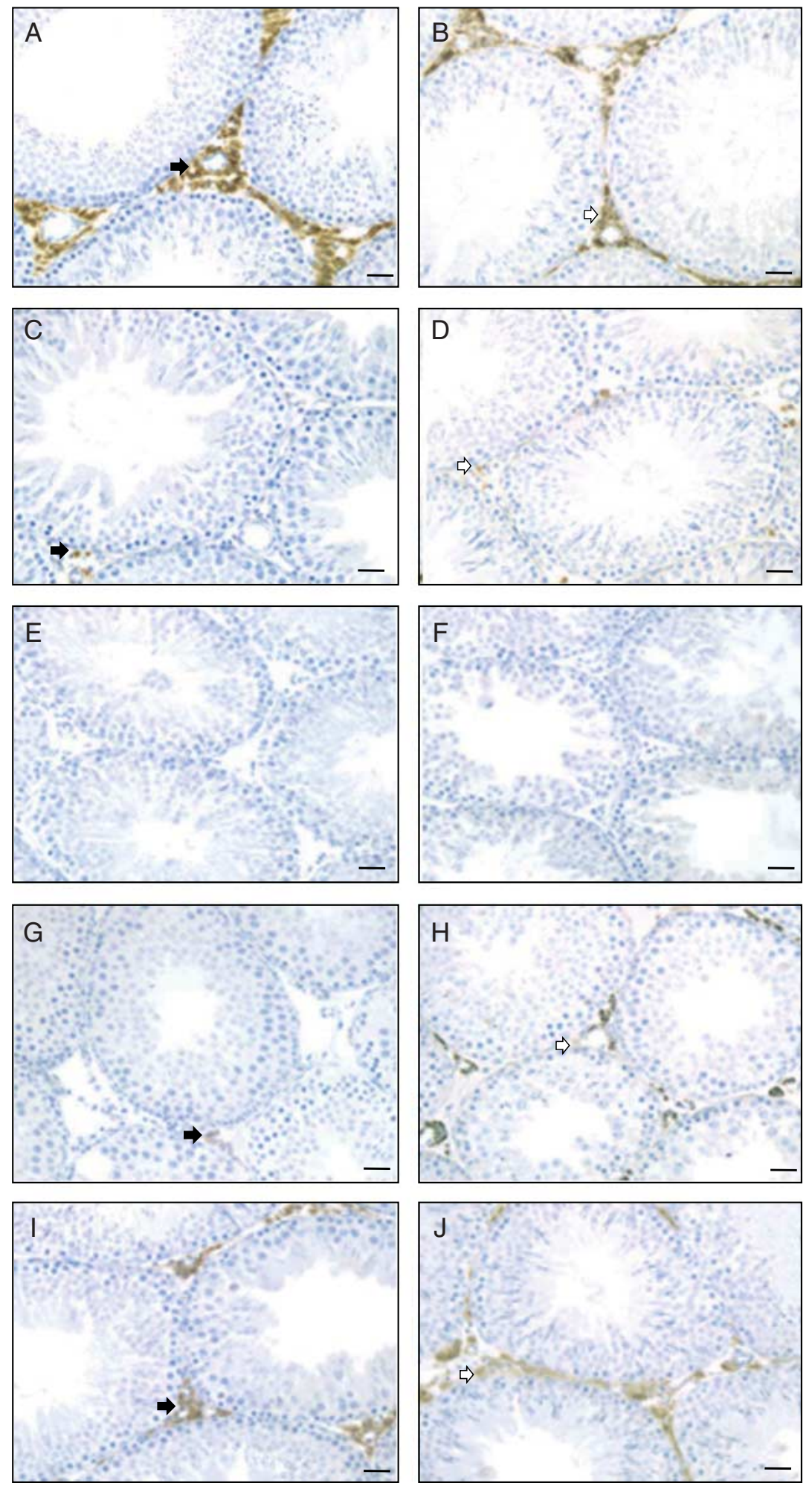

Figure 1 Immunohistochemical staining of $3 \beta \mathrm{HSD} 1$ and $11 \beta \mathrm{HSD} 1$ in rat testes after EDS treatment. $11 \beta \mathrm{HSD}:(\mathrm{A}, \mathrm{C}, \mathrm{E}, \mathrm{G}, \mathrm{I})$ and $3 \beta \mathrm{HSD} 1:(\mathrm{B}, \mathrm{D}, \mathrm{F}, \mathrm{H}, \mathrm{J})$. Sections from testes 0 (control, $A$ and $B$ ),

4 (C and $\mathrm{D}), 14$ (E and $\mathrm{F}), 21(\mathrm{G}$ and $\mathrm{H})$ and 56 (I and J) days post-EDS were shown. The white arrow points to $3 \beta \mathrm{HSD} 1$-positive Leydig cells, and the black arrow points to $11 \beta \mathrm{HSD} 1$-positive Leydig cells. Bar $=50 \mu \mathrm{m}$. regeneration was examined further by measuring testosterone biosynthetic and metabolizing enzyme activities in purified cells. $11 \beta \mathrm{HSD} 1$ was also measured as shown in distinctive development during Leydig cell regeneration. Steroidogenic enzyme activities were measured in intact Leydig cells because homogenization can change the relative rates of oxidative and reductive activities in most hydroxysteroid dehydrogenases. The first step of testosterone biosynthesis is the conversion of cholesterol to pregnenolone, which is catalyzed by 


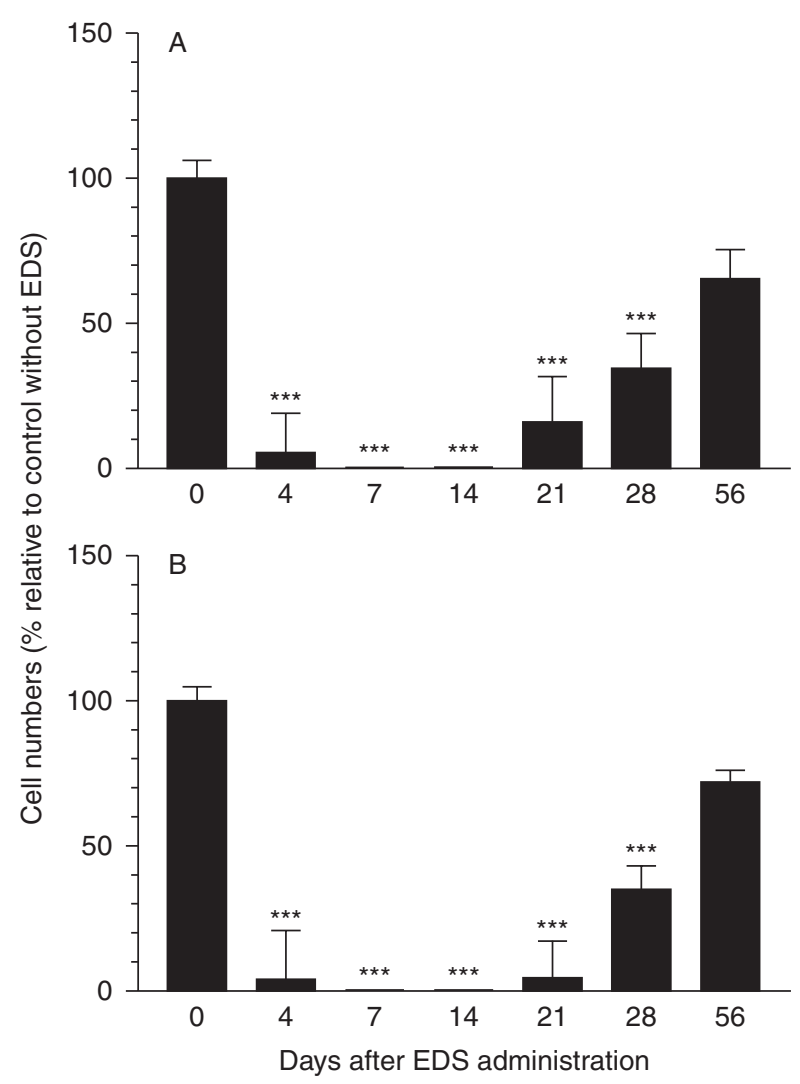

Figure 2 Cell numbers of (A) $3 \beta \mathrm{HSD}$-positive cells and (B) $11 \beta \mathrm{HSD} 1$ positive cells. Mean \pm S.E.M., $n=6 ;{ }^{* * *}$ indicates significant difference compared to control at $P<0.001$.

CYP11A1. The conversion of D5-3 $\beta$-hydroxysteroids to D4-3-ketosteroids is catalyzed by $3 \beta \mathrm{HSD} 1$. CYP17A1 catalyzes both the $17 \alpha$-hydroxylase and the C17-20 lyase reactions to produce androstenedione. The final step of testosterone biosynthesis is catalyzed by $17 \beta \mathrm{HSD} 3$ activity. Androstenedione and testosterone can be metabolized by SRD5A1 and $3 \alpha \mathrm{HSD}$ into androsterone and DIOL respectively. As shown in Fig. 4 the level of CYP11A1 was low in RPLCs and increased during Leydig cell regeneration. $3 \beta \mathrm{HSD} 1$ and CYP17A1 activities in RPLCs were one third of those in ALCs, and the activities of these enzymes in RILCs also reached half of those in ALCs. RPLCs had negligible $17 \beta \mathrm{HSD} 3$ activity. Interestingly, its activity in RILCs was much higher than those in ALCs and RALCs. There was a significant increase in SRD5A1 activity during the transition from RPLCs to RILCs, followed by a sharp decline to barely detectable activity in RALCs. 3aHSD activity was the highest in RILCs and the lowest in ALCs and RALCs (Fig. 4). These results indicate that differential changes in the activities of both testosterone biosynthetic and metabolizing enzymes determine the formation of distinct androgen end products during the Leydig cell regeneration.

\section{Steady-state mRNA levels of steroidogenic enzymes}

Differential changes in testosterone biosynthetic and metabolizing enzyme activities could result from the variation in the steady-state levels of mRNAs that encode these enzymes. Therefore, the steady-state mRNA levels of Leydig cell steroidogenic enzymes were evaluated (Fig. 5) and were found to have similar trends to their respective enzyme activities.

\section{Discussion}

In this study we successfully purified RPLCs, RILCs and RALCs from the EDS-treated rattestes after showing that they were positively stained by $3 \beta \mathrm{HSD}$. Their identities were further distinguished by the immunofluorescent staining of their specific biomarkers. In this regard RPLCs expressed SRD5A1 but not $11 \beta \mathrm{HSD} 1$, RILCs expressed $11 \beta \mathrm{HSD} 1$ but not CYP2A1, and RALCs expressed CYP2A1 but not SRD5A1 (Supplementary Figure 1). It is apparent that the restoration of capacity for testosterone production is achieved not only by increases in testosterone biosynthetic enzymes (CYP11A1, 3ßHSD1, CYP17A1 and $17 \beta \mathrm{HSD} 3)$ but also by concurrent declines in androgenmetabolizing enzymes (SRD5A1 and 3 $\alpha \mathrm{HSD}$ ). Similar to the situation during puberty $5 \alpha$-reduced androgens are high during Leydig cell regeneration.

Steroidogenic capacity is defined as the ability of a cell to produce steroids, whereas the capacity for testosterone production reflects the balance of both testosterone biosynthetic and metabolizing enzyme activities. There is little difference when compared to testicular or circulating androgens, purified RPLCs and RILCs produced different $5 \alpha$-reduced androgens with androsterone primarily in RPLCs and DIOL in RILCs. Formation of DIOL requires $17 \beta \mathrm{HSD} 3$ activities. Direct measurements of enzyme activities in purified cells explained the changes in end products released during Leydig cell regeneration. In RPLCs several androgen biosynthetic enzymes including CYP11A1 and 3BHSD1 attained one third to fifth of the mature values, with the exception of $17 \beta \mathrm{HSD} 3$ that was very low in this cell type, resulting in negligible conversion of androstenedione to testosterone. However, RPLCs readily converted androstenedione to $5 \alpha$-androstanedione by SRD5A1 and ultimately to the androgen end product, androsterone, through $3 \alpha \mathrm{HSD}$, because the activities of both SRD5A1 and $3 \alpha \mathrm{HSD}$ were high. Although most testosterone biosynthetic enzyme (CYP11A1, 3ßHSD1 and CYP17A1) activities nearly attained half the adult values and $17 \beta$ HSD3 activity dramatically increased in RILCs, testosterone formed in this cell type was rapidly metabolized to another androgen end product, DIOL, because of the high expression of SRD5A1 and 3aHSD activities. RALCs contain significantly reduced $3 \alpha \mathrm{HSD}$ activity. However, barely detectable SRD5A1 activity in this cell type limits the catabolism of testosterone to 

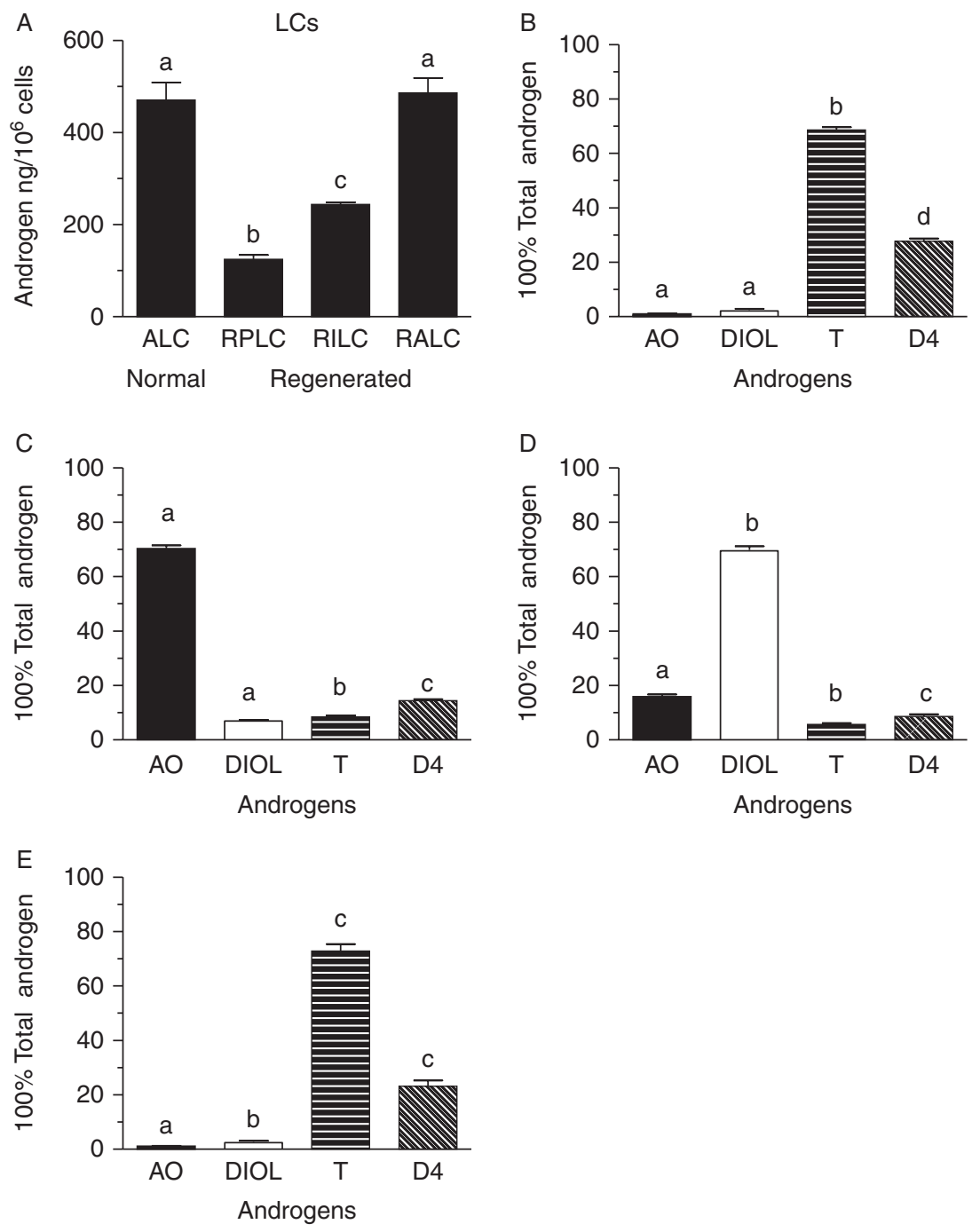

Figure 3 Total androgen levels and primary androgens produced by adult (ALC), regenerated progenitor (RPLC), immature (RILC) and adult (RALC) Leydig cells. ALCs, RPLCs, RILCs and RALCs were isolated from 90-day-old testes or the testes 21, 28 and 56 days post-EDS respectively. The total androgen levels are summed by androsterone (AO), $5 \alpha$-androstane$17 \beta, 3 \alpha$-diol (DIOL), androstenedione (D4) and testosterone (T). A, total androgen levels; B, C, D and E, ALC, RPLC, RILC and RALC respectively. Mean \pm s.E.M., $n=4$ replications. Identical letters indicate no significant difference between groups at $P<0.05$.
$5 \alpha$-reduced androgen, making testosterone the primary androgen end product.

To our surprise, $17 \beta \mathrm{HSD} 3$ activity and its mRNA had the highest levels in RILCs, which was different from those in the immature Leydig cells purified from 35-day-old rat testis (Ge \& Hardy 1998), in which their levels were still lower than those of ALCs isolated from 90-day-old rats. It seems that the regeneration process after EDS is much faster than the normal developmental process during puberty, as indicated by another biomarker 11ßHSD1, an enzyme involved in the glucocorticoid metabolism, which reached adult levels (Fig. 4G) in the RILCs. Normally, $11 \beta \mathrm{HSD} 1$ activity and mRNA level in immature Leydig cells isolated from 35 -day-old rats have only about $50 \%$ of the adult values (Ge et al. 1997). 11ßHSD1 has been shown to be expressed in the Leydig cells at 28 days postpartum and beyond (Phillips et al. 1989). Similarly, $11 \beta$ HSD1-positive cells did not appear until 28 days post-EDS, indicating that $11 \beta \mathrm{HSD} 1$ is a good biomarker for immature and ALCs.
There have been many studies earlier of LC regeneration after EDS treatment (see review by Teerds et al. (2007)). However, these studies were performed in whole testis. The novelty of the present findings is that these regenerated Leydig cells were purified and studied in pure cells. The results from whole testis or pure cells could be different. For example, steroidogenic enzyme activities have been measured in the testis post-EDS administration (Myers \& Abney 1991, O'Shaughnessy \& Murphy 1991). However, these studies reported that DIOL was the primary androgen secreted from the testes on day 21 postpartum. Given the negligible DIOL production that was observed in RPLCs, the predominance of this steroid in this period indicates that other $17 \beta \mathrm{HSD}$ enzymes may also be involved in the reduction of androstenedione into testosterone in peripheral tissues. The present data indicate that the regeneration of steroidogenic enzymes results from sequential, rather than simultaneous, induction of steroidogenic enzyme gene transcription. The steady-state mRNA levels of 


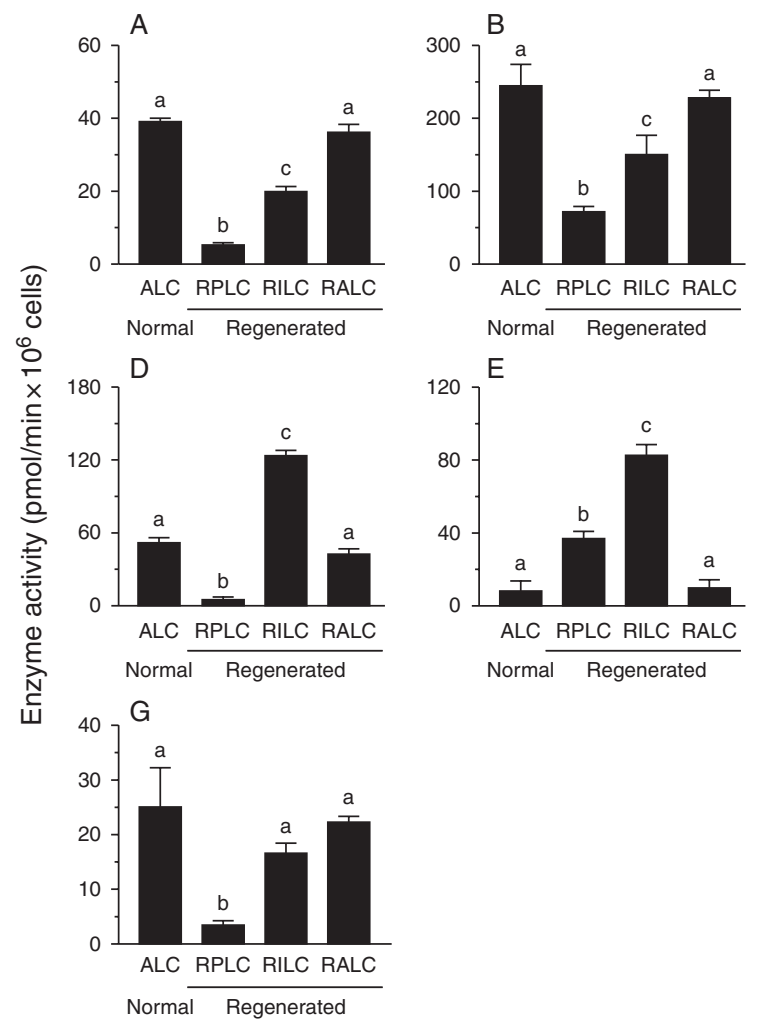

steroidogenic enzymes were measured in Leydig cells to evaluate the relationship between mRNA levels and enzyme activity. We demonstrated that mRNA levels for testosterone biosynthetic enzymes were significantly lower in RPLCs than in RILCs and RALCs. Of the testosterone biosynthetic enzymes, Hsd17b3 was the lowest in RPLCs, consistent with almost undetectable enzyme activity data.

The level of SRD5A1 was the highest in RILCs, followed by RPLCs and RALCs, confirming the transitory expression of this enzyme activity during Leydig cell regeneration. The levels of $3 \alpha \mathrm{HSD}$ and its encoding mRNA (Akr1c14) were the highest in RILCs, which is slightly different from our previous report for its expression levels in the Leydig cell lineage during normal development, among which its expression is the highest in progenitor Leydig cells (Ge \& Hardy 1998). The reason for this discrepancy is still unclear.

It is true that using whole testis measurement of Leydig cell regeneration after EDS showed a similar trend of steroidogenesis recovery (O'Shaughnessy \& Murphy 1991). However, the isolation of Leydig cells and their precursor cells provided more precise information about their androgen production type. The regeneration sequence in the Leydig cell lineage post-EDS is very similar to the counterpart during puberty as described in our previous study (Ge \& Hardy 1998). This sequence of regeneration seems unaffected by Leydig cell environment (niche), as the sperm component of seminiferous tubules during puberty is different from that at
Figure 4 Steroidogenic enzyme activities in Leydig cells. ALCs, RPLCs, RILCs and RALCs were isolated from the testes of 90-day-old rats or the testes 21, 28 and 56 days post-EDS respectively. The levels of Cyp11a1 (A), 33HSD1 (B), CYP17A1 (C), 17ßHSD3 (D), SRD5A1 (E), $3 \alpha \mathrm{HSD}(\mathrm{F})$ and $11 \beta \mathrm{HSD} 1(\mathrm{G})$ were evaluated in Leydig cells. Mean \pm s.E.M., $n=6$ replications. Identical letters indicate no significant difference between groups at $P<0.05$. adulthood. However, Leydig cell regeneration was more rapid in germ-cell-free testis, indicating that germ cells affected Sertoli cells to secret some factors that may be very important for Leydig cell differentiation (O'Shaughnessy et al. 2008).

In conclusion, the present data demonstrate that androgen biosynthetic and metabolizing enzymes are separately modulated in the cell types in the Leydig cell lineage during regeneration post-EDS. This difference has significant consequences for the overall rate of testosterone production.

\section{Materials and Methods}

\section{Chemicals}

$\left[26,27-{ }^{3} \mathrm{H}\right] 25-\mathrm{Hydroxycholesterol,}\left[7-\mathrm{N}-{ }^{3} \mathrm{H}\right]$ pregnenolone, [1 b, 2b- $\left.\mathrm{N}-{ }^{3} \mathrm{H}\right]$ androst-4-ene-3, 17-dione, $\left[1,2,6,7-\mathrm{N}^{3}{ }^{3} \mathrm{H}\right]$ testosterone, $\left[1,2-\mathrm{N}_{-}{ }^{3} \mathrm{H}\right]$ dihydrotestosterone, $5 \alpha-\left[9,11-\mathrm{N}-{ }^{3} \mathrm{H}\right]$ androstane- $17 \beta, 3 \alpha,-$ diol $\left({ }^{3} \mathrm{H}-\mathrm{DIOL}\right),\left[9,11-\mathrm{N}^{-}{ }^{3} \mathrm{H}\right]$ androsterone, and $\left[1,2,6,7-{ }^{3} \mathrm{H}\right]$ corticosterone were purchased from DuPont-New England Nuclear (Boston, MA, USA). [1,2,6,7$\left.\mathrm{N}-{ }^{3} \mathrm{H}\right]$ Progesterone was purchased from Amersham International. ${ }^{3} \mathrm{H}$-11-Dehydrocorticosterone was prepared from labeled ${ }^{3} \mathrm{H}$-corticosterone as described previously (Lakshmi \& Monder 1985). Nonradioactive steroids were purchased from Sigma Chemical Co. or Steraloids (Wilton, NH, USA). 4-Methyl-aza-3-oxo-5a-pregnan-20(S)-carboxylate, an inhibitor of SRD5A1, was provided by Merck. The antibodies for DIOL and androsterone RIA were provided by Dr D T Armstrong 


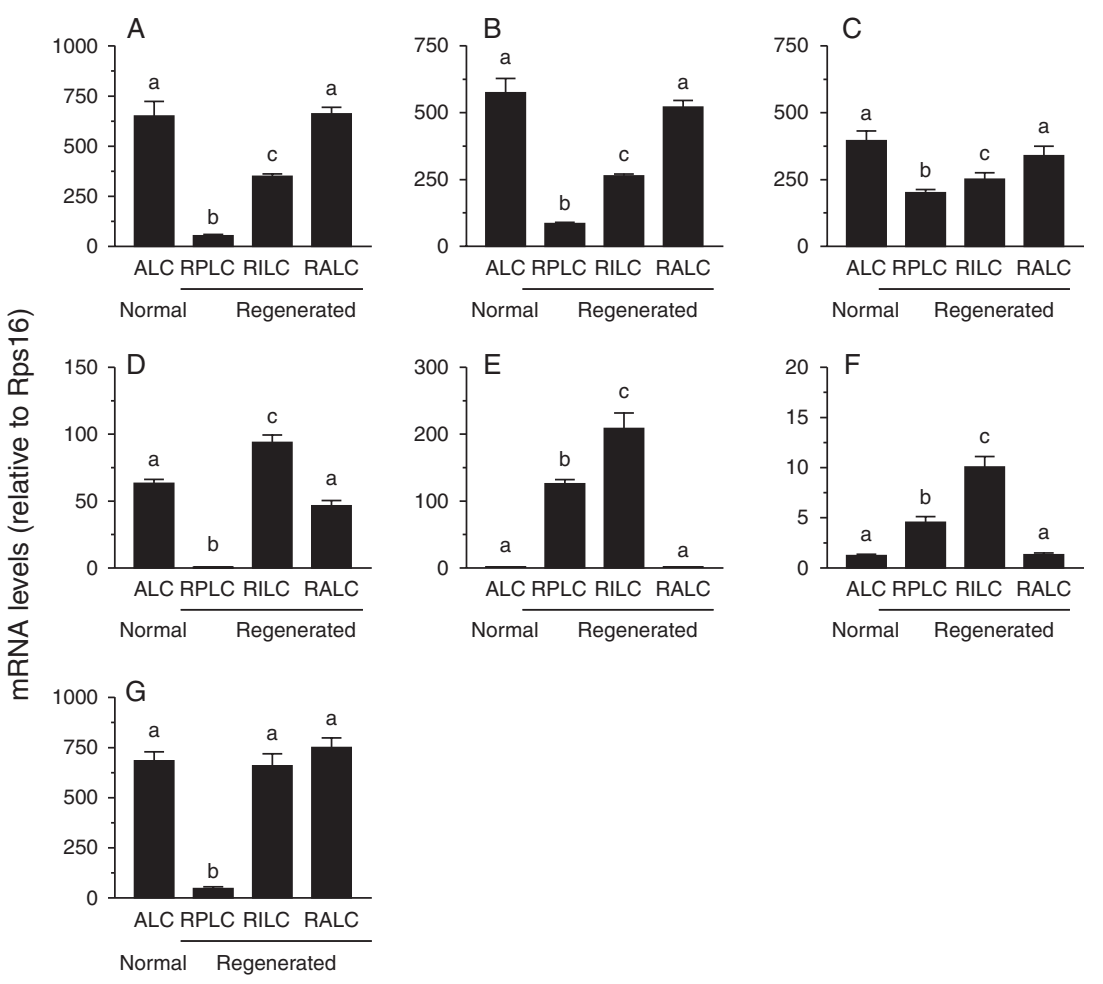

Figure 5 Quantification of steady-state mRNA levels for steroidogenic enzymes in Leydig cells by qPCR. ALCs, RPLCs, RILCs and RALCs were isolated from 90-day-old testes or the testes 21, 28 and 56 days post-EDS respectively. The levels of Cyp11a1 (A), Hsd3b1 (B), Cyp17a1 (C), Hsd17b3 (D), Srd5a1 (E), Akr1c14 (F) and Hsd11b1 (G) were evaluated in Leydig cells. Mean \pm s.E.M., $n=5$ replications. Identical letters indicate no significant difference between groups at $P<0.05$.
(Department of Obstetrics and Gynaecology, University of Western Ontario, London, Ontario, Canada).

\begin{abstract}
Animals
Adult (90-day-old) male Sprague-Dawley rats were purchased from Charles River Laboratories (Wilmington, MA, USA). A total of 72 male rats received i.p. injections of EDS at a dose of $75 \mathrm{mg} / \mathrm{kg}$. Four, 7, 14, 21, 28 and 56 days post-EDS, the animals were killed by asphyxiation with $\mathrm{CO}_{2}$, and testes and blood samples were collected. Some testes from 21, 28 and 56 days post-EDS were used to isolate RPLCs, RILCs and RALCs respectively. An additional 18 normal 90-day-old rats were killed for ALC isolation. The animal protocol was approved by the institutional animal care and use committee of the Rockefeller University.
\end{abstract}

\section{Histological analysis}

Animals were anesthetized by i.p. injection of sodium pentobarbital (25 mg/100 g body weight; Abbott Laboratories). One testis was removed. Then under deep anesthesia, rats were fixed by whole-body perfusion through the left ventricle of the heart with Bouin solution (Wang \& Hardy 2004). Testes were then removed and stored in the fixative overnight. After dehydration in ethanol and xylene testes were embedded in paraffin for immunological analysis. Five testis samples from each group were arrayed in a tissue array rack. Leydig cells were identified through immune-positive staining for the biomarker enzyme 3 $\beta$ HSD1. In brief, $6 \mu \mathrm{m}$-thick transverse sections were prepared and mounted on glass slides (Cat. No. 12-550-15; Fisher Scientific Company, Hampton, NH, USA).
Avidin-biotin immunostaining was performed using a kit (PK6101 for 3BHSD1; Vector Laboratories, Inc., Burlingame, CA, USA) according to the manufacturer's instructions. Antigen retrieval was carried out by microwave irradiation for $10 \mathrm{~min}$ in $10 \mathrm{mM}$ ( $\mathrm{pH}$ 6.0) citrate buffer, and endogenous peroxidase was blocked with $0.5 \% \mathrm{H}_{2} \mathrm{O}_{2}$ in methanol for $30 \mathrm{~min}$. Sections were then incubated with a $3 \beta \mathrm{HSD} 1$ polyclonal antibody diluted 1:3000 (provided by Dr Van Luu-The, Laval University, Quebec, Canada), or $11 \beta \mathrm{HSD} 1$ polyclonal antibody diluted 1:1000 (provided by the Population Council, New York, USA), for $1 \mathrm{~h}$ at room temperature. The antibody-antigen complexes were visualized with diaminobenzidine alone, resulting in brown cytoplasmic staining in positively labeled Leydig cells. The sections were counterstained with Mayer hematoxylin, dehydrated in graded concentrations of alcohol, and coverslipped with resin (Permount, SP15-100; Fisher Scientific). In control experiments sections were incubated with non-immune rabbit IgG $(3 \beta \mathrm{HSD} 1$ or $11 \beta \mathrm{HSD} 1)$ using the same working dilution as the primary antibody.

\section{Cell counts and computer-assisted image analysis}

Twenty randomly selected fields in each of three nonadjacent sections per testis were captured using a Nikon Eclipse E800 microscope (Nikon, Inc., Melville, NY, USA) equipped with a $40 \times$ objective and a SPOT RT digital camera (model 2.3.0.; Diagnostic Instruments, Inc., Michigan City, IN, USA) interfaced to a computer. The images that were displayed on the monitor represented areas of $0.9 \mathrm{~mm}^{2}$ of testis. Interstitial cell numbers were estimated using image analysis software (Image-Pro Plus; Media Cybernetics, Silver Spring, MD, USA). More than 1000 cells of each type were counted in each testis. 
The stereological estimate of Leydig cells was performed according to a previously described method (Akingbemi et al. 2004).

\section{Isolation of Leydig cells}

A complete description of the procedure for isolation of ALCs has been published (Salva et al. 2001). This procedure was also adopted for the isolation of RALCs. Leydig cell isolation was performed using testes from two rats. In brief, testes were removed, perfused via the testicular artery with buffered modified Eagle's medium containing $1 \mathrm{mg} / \mathrm{ml}$ collagenase, decapsulated, and dispersed in a shaking water bath at $34{ }^{\circ} \mathrm{C}$ with $0.25 \mathrm{mg} / \mathrm{ml}$ collagenase. Seminiferous tubules were separated from interstitial cells by adding a modified Eagle's medium containing 1\% BSA and washed twice. The seminiferous tubules were allowed to settle for $1 \mathrm{~min}$ and supernatants were collected by aspiration with a pipette. Cells were then separated by Percoll density gradient centrifugation as described previously (Klinefelter et al. 1987). In brief, the Leydig cell fraction obtained after BSA gradient centrifugation was resuspended in $14 \mathrm{ml} \mathrm{Mg}^{+}$-free HBSS buffered with $0.35 \mathrm{~g} / \mathrm{l}$ sodium bicarbonate and containing $0.25 \% \mathrm{BSA}$ and $25 \mathrm{mg} / \mathrm{l} \mathrm{STI}, \mathrm{pH}$ 7.4. The suspension was thoroughly mixed with $21 \mathrm{ml}$ isosmotic Percoll. A similar $60 \%$ Percoll solution was prepared that contained only 1.062 and $1.075 \mathrm{~g} / \mathrm{ml}$ density marker beads and no cells. The two Percoll solutions were centrifuged in a fixed angle rotor (JA-20, Beckman, Schaumburg, IL, USA) at $20000 \mathrm{~g}$, for $60 \mathrm{~min}$ at $4{ }^{\circ} \mathrm{C}$. Cell types became partitioned due to the various buoyant densities while a continuous, linear density gradient was generated. After centrifugation, the gradient was divided into a lighter than $1.068 \mathrm{~g} / \mathrm{ml}$ fraction consisting of germ cells, macrophages, and damaged Leydig cells, and a $1.068 \mathrm{~g} / \mathrm{ml}$ and heavier fraction containing ALCs or RALCs. ALCs or RALCs were collected from the Percoll gradient at a density of $1.070 \mathrm{~g} / \mathrm{ml}$ and greater. The cells were washed once with modified Hanks' Balanced Salt Solution and centrifuged at $250 \mathrm{~g}$ and then resuspended in $4 \mathrm{ml}$ medium 199 to measure the cell yield.

Isolation of RPLCs from the adult testes 21 days post-EDS was similar to the above procedure with the following alteration. The RPLC fraction was collected between densities of 1.068 and $1.070 \mathrm{~g} / \mathrm{ml}$ as described previously (Shan \& Hardy 1992). Isolation of RILCs from the adult testes 28 days post-EDS was similar to RALC isolation and RILCs were collected between densities of 1.070 and $1.088 \mathrm{~g} / \mathrm{ml}$ as described before (Shan \& Hardy 1992).

The purity of cell fractions was evaluated by histochemical staining for $3 \beta \mathrm{HSD} 1$ activity with $0.4 \mathrm{mM}$ etiocholanolone as a steroid substrate (Payne et al. 1980). Enrichment of the three fractions of Leydig cells was typically more than 95\%. The differentiating identification of ALCs or RALCs from other cell types in the Leydig cell lineage was also performed based on immunohistochemical staining of SRD5A1 and CYP2A1 because these cells did not express SRD5A1 (Ge \& Hardy 1998) but expressed CYP2A1 (Hu et al. 2010). RPLC expressed higher level of SRD5A1 (Ge \& Hardy 1998) but no $11 \beta \mathrm{HSD} 1$ (Ge et al. 2005), while RILCs expressed SRD5A1 (Ge \& Hardy
1998) but also 11ßHSD1 (Ge et al. 1997). However, both RPLCs and RILCs did not express CYP2A1 (Hu et al. 2010).

\section{Immunofluorescent staining of cells in the Leydig cell lineage}

Immunofluorescent staining was performed using Leydig cell lineage cells that were grown on microscope cover glasses. Cells were fixed with $4 \%$ formaldehyde, washed with PBS and permeabilized with $0.1 \%$ (wt/vol) Saponin detergent in PBS - 10\% normal serum. Nonspecific binding was blocked by incubation with $10 \%$ normal serum before addition of the primary antibody. Cells were incubated with polyclonal rabbit anti-11 $\beta$ HSD1 (diluted 1:1000) or anti-SRD5A1 (provided by Dr Robaire B, Department of Pharmacology and Therapeutics, McGill University, Montréal, Québec, Canada, diluted 1:1000) or CYP2A1 (in house) antibodies for $1 \mathrm{~h}$ at room temperature. Cells were then incubated with Alex488-conjugated secondary antibody for $1 \mathrm{~h}$. Afterwards the cells were counterstained with $4^{\prime}, 6^{\prime}$-diamino-2-phenylindole and mounted. The slides were examined under a Nikon fluorescence microscope with a filter suitable for selectively detecting the fluorescence of FITC (green).

\section{Androgen production}

Isolated RPLCs, RILCs and RALCs from EDS-treated testes and ALCs from normal 90-day-old rat testes were incubated at a concentration of $0.1-0.25 \times 10^{6}$ cells $/ \mathrm{ml}$ in Leydig cell culture medium consisting of DMEM and Ham's F-12 medium (D2906, Sigma Chemical Co.) buffered with $15 \mathrm{mM}$ HEPES and $14 \mathrm{mM}$ $\mathrm{NaHCO}_{3}$ and containing $1 \%$ BSA for $3 \mathrm{~h}$ at $34{ }^{\circ} \mathrm{C}$ in a shaking water bath. Incubations of triplicate samples were conducted in medium plus a maximally stimulating dose of ovine $\mathrm{LH}(100 \mathrm{ng} / \mathrm{ml})$. At the end of $3 \mathrm{~h}$ the samples were centrifuged at $500 \mathrm{~g}$. Supernatants were extracted with $2 \mathrm{ml}$ ethyl acetate twice, and the organic layer was dried under nitrogen gas. Steroids in the samples were fractionated using Sephadex LH-20 (Pharmacia Biotech) column chromatography as described previously (Ge \& Hardy 1998). The elution system was chloroform-butane-ethanol (50:50:1, by vol) saturated with distilled water. Clear separation of androstenedione, androsterone, testosterone and DIOL in this system was confirmed using radiolabeled steroids (Ge \& Hardy 1998). The recovery rates following extraction and column separation were used to correct the final concentration measured by RIA. RIAs of androstenedione, androsterone, testosterone and DIOL were performed as described previously (Ge \& Hardy 1998). The results of four separate experiments were averaged for statistical analysis.

\section{Enzyme assay}

With the exception of CYP11A1, steroidogenic enzyme activities were measured by incubation of purified Leydig cells with radiolabeled substrates and separation of products by thin layer chromatography as described previously (Ge \& Hardy 1998). The substrate concentration used for each enzyme was maximal to ensure that the concentration of 
substrate was not rate limiting. Control samples of culture medium alone were run in parallel with each enzyme assay. Briefly, reaction mixture $(0.5 \mathrm{ml})$ was prepared in Leydig cell medium that contained $1 \mu \mathrm{M}$ substrate $(1 \mu \mathrm{Ci})$ in medium. As testosterone undergoes $5 \alpha$-reduction in RPLCs and RILCs, 4-methyl-aza-3-oxo-5a-pregnan-20(S)-carboxylate $(2 \mu \mathrm{M})$ was used to inhibit SRD5A1 when CYP17A1 or $17 \beta \mathrm{HSD} 3$ was measured. The reaction mixture was maintained at $\mathrm{pH}$ 7.2. Reactions were initiated by adding to the reaction medium an aliquot of $0.1-0.2 \times 10^{6}$ Leydig cells. The reaction mixtures, produced in triplicate, were maintained at $34{ }^{\circ} \mathrm{C}$ for $10 \mathrm{~min}$. Reactions were terminated by adding ice-cold ethyl acetate and steroids were rapidly extracted. The organic layer was dried under nitrogen. The radioactivity was measured using a radiometric scanner (System 200/AC3000, Bioscan, Washington, DC, USA). The activity of $3 \beta \mathrm{HSD} 1$ was determined by measuring conversion of ${ }^{3} \mathrm{H}$-pregnenolone to ${ }^{3} \mathrm{H}$-progesterone. The activity of CYP17A1 was determined by measuring conversion of ${ }^{3} \mathrm{H}$-progesterone to ${ }^{3} \mathrm{H}$-androstenedione and ${ }^{3} \mathrm{H}$-testosterone. The activity of $17 \beta \mathrm{HSD} 3$ was determined by measuring the conversion of ${ }^{3} \mathrm{H}$-androstenedione to ${ }^{3} \mathrm{H}$-testosterone. The activity of SRD5A1 was determined by measuring the conversion of ${ }^{3} \mathrm{H}$-testosterone to ${ }^{3} \mathrm{H}$-dihydrotestosterone and ${ }^{3} \mathrm{H}$-DIOL. The activity of $3 \alpha \mathrm{HSD}$ was determined by measuring the conversion of ${ }^{3} \mathrm{H}$-dihydrotestosterone to ${ }^{3} \mathrm{H}$-DIOL. The measurement of $11 \beta \mathrm{HSD} 1$ activity was performed by measuring the conversion of ${ }^{3} \mathrm{H}$-11dehydrocorticosterone to ${ }^{3} \mathrm{H}$-corticosterone according to the previously published method (Ge et al. 2005). The steroids were separated on thin layer chromatographic plates in chloroform-methanol (97:3, vol/vol) for 3 $\beta$ HSD1, 17 $\beta$ HSD3, and SRD5A1 assays; chloroform-methanol (90:10, vol/vol) for $11 \beta \mathrm{HSD} 1$ assay; chloroform-ether (7:1, vol/vol) for CYP17A1 assay; and diethyl ether-acetone $(98: 2, \mathrm{vol} / \mathrm{vol})$ for the $3 \alpha \mathrm{HSD}$ assay.

Activity of CYP11A1 was determined by measuring the conversion of side-chain-labeled $\left[26,27-{ }^{3} \mathrm{H}\right] 25$-hydroxycholesterol to radioactive 4-hydroxyl-4-methyl-pentanoic acid as described previously (Ge \& Hardy 1998). Leydig cells were incubated in a total volume of $0.5 \mathrm{ml}$ medium containing $1 \mu \mathrm{Ci}$ $\left[26,27-{ }^{3} \mathrm{H}\right] 25$-hydroxycholesterol ( $1 \mu \mathrm{M}$ 25-hydroxycholesterol). Incubations were performed for $30 \mathrm{~min}$ at $34{ }^{\circ} \mathrm{C}$, and at the end of incubation, $0.5 \mathrm{ml} \mathrm{NaOH}(0.5 \mathrm{M})$ was added. The mixture was extracted twice with $2 \mathrm{ml}$ chloroform and mixed with neutral alumna to remove non-metabolized substrate, and an aliquot was removed for measurement by liquid scintillation counting.

\section{Real-time PCR (qPCR)}

Levels of steroidogenic enzyme mRNAs were measured by qPCR using the SYBR method following RT of isolated RNA. Briefly, first-strand synthesis and qPCR were performed as described previously (Lin et al. 2009), and the first-strand cDNAs were used as templates for PCR. Quantitative PCR was carried out in a $25-\mu$ l volume using a 96 -well plate format using the SYBR Green PCR Core Reagents purchased from Applied Biosystems. Primer titration was performed and the concentration of $300 \mathrm{nM}$ was selected. Fluorescence was detected using an ABI 7700 system (PE Applied Biosystems).
Each sample was run in duplicate, in parallel with no-template controls. The relative mRNA levels of targeted genes were normalized to ribosomal protein S16 (Rps16, as an internal control) using the standard curve method. All primers in this study were designed by Primer 3 software (Whitehead Institute for Biomedical Research, Cambridge, MA, USA). Forward and reverse primers were placed in different exons to minimize the effects of possible DNA contamination. These genes are CYP11A1 (Cyp11a1), CYP17A1 (Cyp17a1), 3ßHSD1 (Hsd3b1), 17ßHSD3 (Hsd17b3), SRD5A1 (Srd5a1), 3aHSD (Akr1c14), and 11 $\beta$ HSD1 (Hsd11b1). The primers used were described previously (Ge et al. 2005, Lin et al. 2008).

\section{Statistical analysis}

The data were analyzed by one-way ANOVA followed by ad hoc Turkey's multiple comparison test using GraphPad (Version 5, GraphPad Software, Inc., San Diego, CA, USA). All data were expressed as means \pm s.E.M. Differences were regarded as significant at $P<0.05$.

\section{Supplementary data}

This is linked to the online version of the paper at http://dx.doi. org/10.1530/REP-12-0465.

\section{Declaration of interest}

The authors declare that there is no conflict of interest that could be perceived as prejudicing the impartiality of the research reported.

\section{Funding}

This work was supported by the NSFC (30871434, 31171425, 81102092, 30900846, 81070477).

\section{Acknowledgements}

The authors gratefully acknowledged the technical assistance of Ms Chantal M Sottas. They also thank Dr Armstrong D T for providing antibodies to androsterone and androstanediol, Dr Robaire B, Department of Pharmacology and Therapeutics, McGill University, Montréal, Québec, Canada, for SRD5A1 antibody and Dr Luu-The V, Laval University, Quebec, Canada, for $3 \beta \mathrm{HSD} 1$ antibody.

\section{References}

Akingbemi BT, Ge R, Klinefelter GR, Zirkin BR \& Hardy MP 2004 Phthalate-induced Leydig cell hyperplasia is associated with multiple endocrine disturbances. PNAS 101 775-780. (doi:10.1073/pnas. 0305977101)

Ariyaratne HB, Mendis-Handagama SM, Hales DB \& Mason IJ 2000 Studies of the onset of Leydig cell differentiation in the prepubertal rat testis. Biology of Reproduction 63 165-171. (doi:10.1095/biolreprod63. $1.165)$ 
Bartlett JM, Kerr JB \& Sharpe RM 1986 The effect of selective destruction and regeneration of rat Leydig cells on the intratesticular distribution of testosterone and morphology of the seminiferous epithelium. Journal of Andrology 7 240-253.

Davidoff MS, Middendorff R, Enikolopov G, Riethmacher D, Holstein AF \& Muller D 2004 Progenitor cells of the testosterone-producing Leydig cells revealed. Journal of Cell Biology 167 935-944. (doi:10.1083/jcb. 200409107)

Ge RS \& Hardy MP 1998 Variation in the end products of androgen biosynthesis and metabolism during postnatal differentiation of rat Leydig cells. Endocrinology 139 3787-3795. (doi:10.1210/en.139.9. 3787)

Ge RS \& Hardy MP 2007 Regulation of Leydig cells during pubertal development. In The Leydig Cell in Health and Disease, pp 55-70. Eds AH Payne \& MP Hardy. Totowa: Humana Press.

Ge RS, Hardy DO, Catterall JF \& Hardy MP 1997 Developmental changes in glucocorticoid receptor and $11 \beta$-hydroxysteroid dehydrogenase oxidative and reductive activities in rat Leydig cells. Endocrinology 138 5089-5095. (doi:10.1210/en.138.12.5089)

Ge R-S, Dong Q, Niu E-M, Sottas CM, Hardy DO, Catterall JF, Latif SA, Morris DJ \& Hardy MP $200511 \beta$-Hydroxysteroid dehydrogenase 2 in rat Leydig cells: its role in blunting glucocorticoid action at physiological levels of substrate. Endocrinology 146 2657-2664. (doi:10.1210/en. 2005-0046)

Ge RS, Dong Q, Sottas CM, Papadopoulos V, Zirkin BR \& Hardy MP 2006 In search of rat stem Leydig cells: identification, isolation, and lineagespecific development. PNAS 103 2719-2724. (doi:10.1073/pnas. 0507692103)

Hu GX, Lian QQ, Lin H, Latif SA, Morris DJ, Hardy MP \& Ge RS 2008 Rapid mechanisms of glucocorticoid signaling in the Leydig cell. Steroids 73 1018-1024. (doi:10.1016/j.steroids.2007.12.020)

Hu GX, Lian QQ, Chen BB, Prasad PV, Kumar N, Zheng ZQ \& Ge RS 2010 $7 \alpha$-Hydroxytestosterone affects $1 \beta$-hydroxysteroid dehydrogenase 1 direction in rat Leydig cells. Endocrinology 151 748-754. (doi:10.1210/ en.2009-0917)

Klinefelter GR, Hall PF \& Ewing LL 1987 Effect of luteinizing hormone deprivation in situ on steroidogenesis of rat Leydig cells purified by a multistep procedure. Biology of Reproduction 36 769-783. (doi:10.1095/biolreprod36.3.769)

Lakshmi V \& Monder C 1985 Extraction of $11 \beta$-hydroxysteroid dehydrogenase from rat liver microsomes by detergents. Journal of Steroid Biochemistry 22 331-340. (doi:10.1016/0022-4731(85)90435-2)

Lin H, Ge RS, Chen GR, Hu GX, Dong L, Lian QQ, Hardy DO, Sottas CM, Li XK \& Hardy MP 2008 Involvement of testicular growth factors in fetal Leydig cell aggregation after exposure to phthalate in utero. PNAS 105 7218-7222. (doi:10.1073/pnas.0709260105)

Lin $\mathrm{H}$, Lian QQ, Hu GX, Jin Y, Zhang Y, Hardy DO, Chen GR, Lu ZQ, Sottas CM, Hardy MP et al. 2009 In utero and lactational exposures to diethylhexyl-phthalate affect two populations of Leydig cells in male long-evans rats. Biology of Reproduction 80 882-888. (doi:10.1095/ biolreprod.108.072975)
Myers RB \& Abney TO 1991 Interstitial cell proliferation in the testis of the ethylene dimethane sulfonate-treated rat. Steroids 56 91-96. (doi:10. 1016/0039-128X(91)90130-N)

Neumann A, Haider SG \& Hilscher B 1993 Temporal coincidence of the appearance of elongated spermatids and of histochemical reaction of $11 \beta$-hydroxysteroid dehydrogenase in rat Leydig cells. Andrologia 25 263-269. (doi:10.1111/j.1439-0272.1993.tb02723.x)

O'Shaughnessy PJ \& Murphy L 1991 Steroidogenic enzyme activity in the rat testis following Leydig cell destruction by ethylene-1,2-dimethanesulphonate and during subsequent Leydig cell regeneration. Journal of Endocrinology 131 451-457. (doi:10.1677/joe.0.1310451)

O'Shaughnessy PJ, Morris ID \& Baker PJ 2008 Leydig cell re-generation and expression of cell signaling molecules in the germ cell-free testis. Reproduction 135 851-858. (doi:10.1530/REP-07-0529)

Payne AH, Downing JR \& Wong KL 1980 Luteinizing hormone receptors and testosterone synthesis in two distinct populations of Leydig cells. Endocrinology 106 1424-1429. (doi:10.1210/endo-106-5-1424)

Phillips DM, Lakshmi V \& Monder C 1989 Corticosteroid 11 $\beta$-dehydrogenase in rat testis. Endocrinology 125 209-216. (doi:10.1210/endo125-1-209)

Salva A, Klinefelter GR \& Hardy MP 2001 Purification of rat Leydig cells: increased yields after unit-gravity sedimentation of collagenasedispersed interstitial cells. Journal of Andrology 22 665-671.

Shan LX \& Hardy MP 1992 Developmental changes in levels of luteinizing hormone receptor and androgen receptor in rat Leydig cells. Endocrinology 131 1107-1114. (doi:10.1210/en.131.3.1107)

Teerds KJ 1996 Regeneration of Leydig cells after depletion by EDS: a model for postnatal Leydig cell renewal. In The Leydig Cell, pp 203-220. Eds AH Payne, MP Hardy \& LD Russell. Vienna, IL: Cache River Press.

Teerds K, Veldhuizen-Tsoerkan MB, Rommerts FF, de Rooij DG \& Dorrington J 1994 Proliferation and differentiation of testicular interstitial cells: aspects of Leydig cell development in the (pre) pubertal and adult testis. In Molecular and Cellular Endocrinology of the Testis, pp 37-65. Eds G Verhoeven \& UF Habenicht. New York: Springer-Verlag.

Teerds KJ, Rijntjes E, Veldhuizen-Tsoerkan MB, Rommerts FF \& de BoerBrouwer M 2007 The development of rat Leydig cell progenitors in vitro: how essential is luteinizing hormone? Journal of Endocrinology 194 579-593. (doi:10.1677/JOE-06-0084)

Vreeburg JT, Ooms MP, Rommerts FF \& Teerds KJ 1988 Functional properties of developing rat Leydig cells after treatment with ethylene dimethanesulphonate (EDS). Journal of Reproduction and Fertility $\mathbf{8 4}$ 63-69. (doi:10.1530/jrf.0.0840063)

Wang G \& Hardy MP 2004 Development of Leydig cells in the insulin-like growth factor-I (IGF-I) knockout mouse: effects of igf-I replacement and gonadotropic stimulation. Biology of Reproduction 70 632-639. (doi:10.1095/biolreprod.103.022590)

Received 18 November 2012

First decision 20 December 2012

Accepted 31 January 2013 